\title{
Zadania instytucji edukacji dla bezpieczeństwa na potrzeby bezpieczeństwa państwa
}

\section{KEYWORDS}

education for safety, education, principles of John Amos Comenius, John Locke, Immanuel Kant

\begin{abstract}
Martuszewska Jolanta, Zadania instytucji edukacji dla bezpieczeństwa na potrzeby bezpieczeństwa państwa [Tasks of safety education institutions concerning the needs of state security]. Kultura - Społeczeństwo - Edukacja nr 1(17) 2020, Poznań 2020, pp. 399-410, Adam Mickiewicz University Press. ISSN 2300-0422. DOI 10.14746/ kse.2020.17.15.1
\end{abstract}

The desire to live a safe life is one of the most important human needs, while education is the basis of knowledge of the society as a whole. To ensure the safety of the individual and the security of the state, there is a need for stable cooperation between various security institutions. There are many safety education institutions that work for the needs of state security. These include the Education for Safety Bureau, the post of Education for Safety Inspector, the post of School Safety Coordinator, School Safety Clubs, etc. The aim of this paper is to describe the situation in education based on safety education teaching in the 21 st century. Other objectives include indicating tasks and rational solutions in education on the basis of the principles introduced by scholars, such as J.A. Comenius, J. Locke, I. Kant, which remain valid to this day.

\section{Wstęp}

Bezpieczeństwo to stan spokoju oraz pewności braku zagrożenia. Odnosi się do każdego człowieka, grupy ludzi, narodu, obiektu, regionu czy też państwa. Jest

\footnotetext{
* ORCID https://orcid.org/0000-0002-6386-9534.
} 
wartością niezbywalną i niewymienialną, konieczną, życiową i potrzebną. Jako wartość fundamentalna w hierarchii aksjologicznej zajmuje jedno z najwyższych miejsc.

Bezpieczeństwa nie cenimy ze względu na nie samo, ale dlatego, że zapewnia i gwarantuje nam inne cenne wartości, takie jak życie, zdrowie, sukces, majątek, nabyte prawa i świadczenia, oraz stanowi środek do ich osiągnięcia bądź zachowania.

Poczucie bezpieczeństwa jest subiektywne, oznacza: nie odczuwać zagrożenia, nie lękać się, nie bać się. Zaznaczyć należy jednak, iż przekonanie lub przeświadczenie nie jest dowodem jego istnienia. Antonimem bezpieczeństwa jest zagrożenie. „Zagrażać” - to „postraszyć czymś kogoś, zapowiedzieć coś złego, groźba jakichś konsekwencji (...) lub stać się niebezpiecznym dla kogoś lub czegoś" (Doroszewski, 2009).

„Zagrożenie może dotyczyć człowieka (ludzi), jego zdrowia, bezpieczeństwa, egzystencji, szczęścia, rzeczy materialnych, dobytku ludzi, urządzeń, budowli, miast, regionów, państw (...), ale także wody, żywności, atmosfery, zwierząt, całej przyrody, a nawet kosmosu" (Doroszewski, 2009). Przy czym, w zależności od indywidualnej sytuacji, w jakiej się znajdujemy, inne czynniki będą powodowały stan zagrożenia i poczucie niepewności, jednak nie będą wpływać na posiadaną wiedzę. Inaczej zatem artykułować będziemy swoje potrzeby w zakresie realizacji prawa do bezpieczeństwa.

Bezpieczeństwo kojarzy się z istniejącym zagrożeniem. Każdy człowiek inaczej odczuwa zagrożenie oraz inaczej pojmuje poczucie (nie)pewności. Natomiast wiedza o zagrożeniach, sposobach uniknięcia ich oddziaływania i zmniejszenie ich skutków powinno być każdemu znane.

Odpowiedzialność za stan bezpieczeństwa spoczywa na władzach rządowych i samorządowych oraz instytucjach do tego powołanych. Stwierdzić należy, iż poczucie bezpieczeństwa określane jest zarówno przez czynniki obiektywne, wymierne, jak i subiektywne, trudno wymierne i nie zawsze racjonalne (Doroszewski, 2009).

Zapewnienie bezpieczeństwa wiąże się z potrzebą używania różnorakich narzędzi. Można do nich zaliczyć między innymi:

- organa władzy państwowej i samorządowej,

- organa dyplomatyczne i konsularne,

- siły i służby zmilitaryzowane,

- organizacje pozarządowe.

Nie bez znaczenia pozostaje także jakość władzy, polityka państwa, morale narodu, stan i przestrzeganie prawa państwowego, poziom kultury narodowej, nauki, edukacji itp. 
Teorią i praktyką bezpieczeństwa jest polityka bezpieczeństwa narodowego. Dotyczy sposobów świadomego oddziaływania państwa na środowisko, jego bezpieczeństwa za pomocą określonych narzędzi (instrumentów) i środków, dla osiągnięcia celów założonych przez podmioty polityki bezpieczeństwa narodowego.

Rozwój właściwie zorganizowanego systemu bezpieczeństwa państwa jest podstawowym zadaniem polskiej polityki bezpieczeństwa. (...) w tworzeniu i realizacji tej polityki powinny uczestniczyć szerokie kręgi naszego społeczeństwa. Szczególnie istotne znaczenie ma połączenie sił administracji samorządowej i społeczności lokalnej, gdyż mieszkańcy gmin i ich władze urzeczywistniają w praktyce cele polityki bezpieczeństwa. (Strategia Bezpieczeństwa Narodowego..., 2014: 36)

W celu umacniania i kształtowania pożądanego stanu bezpieczeństwa dla realizacji swoich zadań powstają wyspecjalizowane instytucje oraz służby, które w ramach swoich kompetencji odpowiadają za poszczególne dziedziny bezpieczeństwa, monitorują jego stan i podejmują stosowne do jego potrzeb działania.

\section{Edukacja dla bezpieczeństwa - zadania, cele, wyzwania}

Zasadniczym przedmiotem troski o zapewnienie bezpieczeństwa jest człowiek, ochrona jego życia i zdrowia, mienia, a także środowiska, w którym mieszka, uczy się i pracuje. Polityka bezpieczeństwa państwa powinna być skupiona na tych kwestiach. Tak ukierunkowane bezpieczeństwo jest warunkiem harmonijnego funkcjonowania jednostek i ich rozwoju, co przekłada się na rozwój i funkcjonowanie grup lokalnych, społeczeństw (narodów) i pośrednio na społeczność międzynarodową. Podkreślić przy tym należy, iż bez zapewnienia poczucia bezpieczeństwa jednostce niemożliwy jest postęp i rozwój społeczny.

Już w starożytności ukształtowały się dwie tendencje związane z przysposabianiem do obrony. Pierwsza to należyte przygotowanie żołnierzy do walki, druga zaś dotyczyła powszechnej aktywności obywatelskiej na rzecz obrony. Zadania te prowadzono w różnych formach.

Immanuel Kant porównuje oświecenie do wyjścia człowieka z niedojrzałości. Uważa, iż wiąże się to $\mathrm{z}$ brakiem umiejętności posługiwania się rozumem i poddawaniu się przewodnictwu innych (Kupś, 2005: 44-45; Szymaniec, 2009). Z drugiej strony podkreśla, iż jest to wygodne, aby szukać wymówek zamiast zabrać się do działania (Kupś, 2005: 48-49). Praktyczne podejście do tematyki lokalnych zagrożeń, na przykład braku prądu, wody, gazu, pozwoli przedstawić pewien schemat postępowania, aby wiedzieć, jak się zachować w takiej sytuacji. 
Instytucje lokalne powinny wychodzić poza schematy (rozporządzenia, biurokracje), odważnie, a jednocześnie kreatywnie podejmować tematy wspólnie ze szkołami, mieszkańcami, aby tematyka zagrożeń stała się znana także osobom starszym. Ćwiczenia z praktykami i specjalistami pozwolą przybliżyć, uświadomić, przećwiczyć działania w konkretnych sytuacjach, na przykład reagowanie w sytuacji zagrożenia życia.

Według filozofa państwo jest „instytucją rozumną", postępuje z zasadami moralnymi oraz wartościami. Państwo jako silny podmiot dba o swoje żywotne interesy oraz egzystencję (Grabowska, 2011: 235-248). We wczesnym stadium nauczania ma obowiązek edukowania młodych ludzi oraz formowania ich systemu wartości, by dążeniem była jednostka, naród, państwo.

Człowiek według Johna Locke’a to istota rozumna (Grabowska, 2011: 243). Z kolei rozumność umożliwia niezależność umysłu oraz jest ściśle związana $z$ wolnością. Filozof uzasadnia, iż odpowiednia nauka może zdziałać wiele. Zaznacza, że skoro ciało można kształtować poprzez ćwiczenia, to i rozum będzie na takie działania podatny (Locke, 1969: 608). Gdy rozum kieruje naszym postępowaniem, powściąga instynkty i namiętności, tym lepszy użytek potrafimy zrobić z wolności. Ćwiczenia praktyczne i treści podstawy programowej przedmiotu edukacja dla bezpieczeństwa powinny być realizowane $\mathrm{w}$ równych proporcjach.

Bez rozumu wolność staje się niebezpieczna. Człowiek, mając prawo do wyboru, może wybrać źle. Wszystkie błędy w ten sposób popełniane wynikają z niedostatecznych umiejętności posługiwania się rozumem, zwłaszcza ze zbyt szybkiego przechodzenia do działania (Grabowska, 2011: 245).

Doskonaląc rozum (zadanie szkoły, nauczyciela, ucznia), można zminimalizować niebezpieczeństwa wynikające z wolności. Ważne jest rozwijanie zdolności umysłowych w zgodzie z rozumem. Zadaniem szkoły jest czuwanie nad prawidłowym procesem kształcenia.

Filozof w kwestii wykształcenia młodzieży w Myśli o wychowaniu (Locke, 1959: 205) przedstawia program wychowawczy dla przyszłych gentlemenów. Jego celem jest wszechstronny rozwój umysłowy i fizyczny wychowanków, którzy mają stać się zdolni do służby dla kraju. Według Locke’a najważniejszym celem wychowania jest osiągnięcie stanu, w którym rozum w jak największej mierze kieruje naszymi wyborami i następującymi po nich czynami. Kierowanie się rozsądkiem, pewność siebie i podejmowanie właściwych decyzji na przykład w sytuacji zagrożenia życia ludzkiego jest wręcz potrzebną umiejętnością.

Instrumentami, które zapewniają społeczne i polityczne porozumienie w kwestii bezpieczeństwa, są edukacja obywatelska, dialog społeczny, współpraca par- 
lamentarna, a także Rada Bezpieczeństwa Narodowego (Strategia Bezpieczeństwa Narodowego..., 2014: 25). Natomiast

(...) potencjał społeczny, w tym kapitał ludzki, jest ważnym czynnikiem warunkującym wzrost gospodarki narodowej, sprawność państwa, aktywność społeczeństwa obywatelskiego oraz ogólną poprawę jakości życia obywateli. Nowoczesny system edukacji publicznej i szkolnictwa wyższego, a także upowszechnienie różnych form uczenia się przez całe życie służą wykształceniu społeczeństwa aktywnego i mobilnego. Istotnym elementem rozwoju kapitału ludzkiego i społecznego jest edukacja na rzecz bezpieczeństwa. (Strategia Bezpieczeństwa Narodowego..., 2014: 14)

Zatem potencjał społeczny warunkuje sprawność państwa, aktywność społeczeństwa obywatelskiego. Przedmiot edukacja na rzecz bezpieczeństwa może stanowić niepodważalny element $\mathrm{w}$ zachowaniu stabilności państwa przez przygotowanie młodzieży do przeciwdziałania i walki z zagrożeniami.

Zadaniem edukacji dla bezpieczeństwa jest upowszechnienie wiedzy z zakresu bezpieczeństwa obywatela także w jego środowisku lokalnym (Strategia Bezpieczeństwa Narodowego..., 2014: 39). Priorytetem jest podnoszenie świadomości społecznej w kwestii rozumienia zagrożeń dla bezpieczeństwa oraz kształtowania kompetencji pozwalających w sposób celowy i racjonalny reagować na nie. Celem edukacyjnym nauczycieli powinno być nie tyle wyposażenie uczniów w wiedzę, co zastosowanie wiedzy w praktyce. Istotne jest zwiększanie efektywności działania administracji publicznej w sprawach bezpieczeństwa poprzez ustawiczne podnoszenie kwalifikacji i zdolności do skutecznego reagowania na zagrożenia.

Podnoszenie kompetencji instytucji edukacji dla bezpieczeństwa w obszarze bezpieczeństwa wymaga intensyfikacji i lepszego skoordynowania. Ważne jest nieustanne podnoszenie jakości kształcenia, które wpływa na bezpieczeństwo państwa w powszechnym systemie edukacji, szkolnictwie wyższym oraz doskonaleniu zawodowym, żołnierzy, funkcjonariuszy, personelu cywilnego wojska i służb, pracowników administracji publicznej oraz nauczycieli przedmiotu edukacja dla bezpieczeństwa (Strategia bezpieczeństwa narodowego..., 2014: 52).

Realizowana jest przez szkolnictwo powszechne i wyższe, centralne i lokalne instytucje państwowe oraz stowarzyszenia i organizacje pozarządowe.

\section{Edukacja w szkole XXI wieku}

Podstawowe funkcje szkoły, oprócz opieki nad powierzonymi placówkom dziećmi, definiuje się jako wychowanie, polegające na kształtowaniu postaw, oraz dydaktykę, 
której celem powinno być przekazywanie wiedzy i kształcenie umiejętności (Kmita, 1991). Edukacja jest fundamentem rozwoju, a postęp i jakość życia w coraz większym stopniu zależeć będą od poziomu wiedzy społeczeństwa oraz umiejętności jej wykorzystywania.

Istotne jest zwiększanie świadomości uczniów o zagrożeniach poprzez intensyfikację działań edukacyjnych na wszystkich poziomach nauczania, a także w formie szkoleń i kampanii społecznych. Dlatego szkolnictwo powinno dostosować się do zmieniającej się rzeczywistości i wprowadzać innowacyjne zmiany. Szkoła potrzebuje zmian, gdyż (Raport z narad obywatelskich o edukacji, 2019: 18-28):

- zdobyte umiejętności i postawy w niewielkim stopniu kształtują oraz rozwijają wiedzę poprzez praktyczne działania i doświadczenie;

- przekazuje w nadmiarze teoretyczną wiedzę uczniom kosztem pozostałych funkcji. Podawana w szkole wiedza jest często określana jako „zbędna”, „encyklopedyczna” czy „krzyźówkowa”;

- w programach nauczania przekazuje zbyt mało wiedzy praktycznej i kompetencji przydatnych w dalszym życiu. Ważne jest kształtowanie wśród uczniów tak zwanych kompetencji miękkich „czyli umiejętności życiowych, rozumianych jako zdolność do adaptacji i pozytywnych zachowań, umożliwiających jednostce skuteczne radzenie sobie $\mathrm{z}$ wymaganiami i wyzwaniami życia codziennego" (WHO, 1994). Owe umiejętności pozwolą odpowiednio korzystać ze zdobywanej wiedzy teoretycznej, między innymi umiejętności kreatywnego myślenia, filtrowania informacji, samodzielnego uczenia się. Jest to niezbędne do prawidłowego funkcjonowania we współczesnym społeczeństwie;

- poza rozwijaniem postawy obywatelskiej szkoła nie wzmacnia wśród uczniów postaw związanych z solidarnością, szczególnie międzypokoleniowych umiejętności, postaw oraz empatii.

Tabela 1. Odpowiedzi na pytania: Jak szkoła uczy i wychowuje? Jak motywuje do nauki? Jakich doświadczeń dostarcza?

\begin{tabular}{|l|l|}
\hline \multicolumn{1}{|c|}{ Jak jest w szkole? } & \multicolumn{1}{c|}{ Co można zmienić? } \\
\hline - nie uczy myślenia, & - diagnoza wskazówką dla ucznia, nauczyciela, \\
- przeładowany program, & rodziców, \\
- sposób przekazywania trudnych treści & - pozytywne motywowanie, \\
nieadekwatny do wieku dziecka, & - zwiększanie interakcji nauczyciel - uczeń, \\
- testonomia, diagnozowanie, & - uczenia praktyczne z nawiązaniem do życia, \\
- nierówny poziom, & - nauka logicznego myślenia, \\
- za mało kontaktu z uczniem, & - różnorodność metod nauczania, \\
- przygotowuje do egzaminów, & - metoda projektów, \\
- osamotniona: brak wsparcia władz, & - podstawa programowa przystająca do życia \\
& samorządów, \\
\hline
\end{tabular}


- etapowość,

- system egzaminów powoduje, że nauczyciele są rozliczani przez rodziców przede wszystkim z wyników egzaminów,

- brak relacji/dialogu,

- presja sukcesu i edukacyjnej wartości dodanej,

- papierologia,

- narzędzia w miejsca celów,

- metoda nauczania tymi samymi sposobami,

- uczenie „pod egzaminy”, wiedza bez umiejętności, nauczanie pamięciowe, schematyczne, ujednolicone, nieżyciowe,

- kreuje rywalizację w negatywnym znaczeniu, „wyścig szczurów” poprzez zbyt duży nacisk na oceny,

- zbyt liczne klasy,

- ocenianie wpisane w system kontroli służy wykryciu błędów i odstępstw od wzorca,

- nacisk na kontrolę powoduje stres, strach i poczucie bezradności, tym samym blokuje uczenie się i rozwój,

- taki system oceniania promuje konkurowanie („wyścig szczurów”),

- dzieli uczniów na dobrych i słabych. Konkurowanie nie zachęca do współpracy i działań zespołowych.
- szkoła wolna od ideologii politycznych,

- szkoła ma spełniać funkcję centrum kulturalnego dla społeczności lokalnej,

- uwzględniać różnice i talenty indywidualne,

- indywidualizacja i personalizacja procesów nauczania, uwzględnienie różnych dróg i tempa dochodzenia do zamierzonych rezultatów oraz wymóg wygospodarowania czasu na indywidualne spotkania,

- nauczanie problemowe i blokowe,

- zmniejszenie liczby uczniów w grupie do 13 osób, aby była przestrzeń na nawiązanie relacji uczeń- nauczyciel i uczeń -uczeń,

- elastyczny podział uczniów na grupy, które realizowałyby wybrane moduły przedmiotu,

- klasa dwujęzyczna od czwartej klasy,

- zajęcia uczące „kompetencji miękkich” od pierwszej klasy,

- nie etykietuje uczniów, nie dzieli na kategorie, nie tworzy rankingów. Tym samym zachęca do współpracy, wspólnego poszukiwania rozwiązań i dzielenia się doświadczeniem. Zaufanie jest warunkiem rozwoju i rzeczywistego uczenia się,

- rozmowa wstępna zamiast egzaminu,

- uczenie myślenia,

- brak prac domowych.

Źródło: opracowanie na podstawie: Narada obywatelska o edukacji..., 2019: 18-28

Kluczową rolę w systemie edukacji odgrywają nauczyciele, którzy przekazują wiedzę (ryc. 1). Powinno temu towarzyszyć podnoszenie poziomu kompetencji i umiejętności profesjonalnego wykorzystywania zaawansowanej techniki oraz narzędzi informatycznych.

Uczenie się powinno być istotą i sensem działania szkoły, natomiast umiejętności i postawy rozwijane oraz kształtowane są poprzez praktyczne działanie nauczyciela. Popełniane błędy (co w działaniu jest nieuniknione) pozwalają wyciągać wnioski i weryfikować przyjęte założenia. Taki proces uczenia się, wspierany przez nauczyciela, może rozwijać ucznia i motywować do dalszego działania.

Zadaniem przedmiotu edukacja dla bezpieczeństwa jest upowszechnienie wiedzy z zakresu bezpieczeństwa obywatela także w jego środowisku lokalnym. Szkoła może być ośrodkiem życia lokalnego, miejscem, w którym chętnie przebywa się poza godzinami lekcji - w którym spotykają się mieszkańcy. Odbywa się współpraca z otoczeniem (rodziny, przedsiębiorcy, instytucje), podejmuje się inicjatywy integrujące społeczność oraz dzieli się umiejętnościami i wiedzą. 


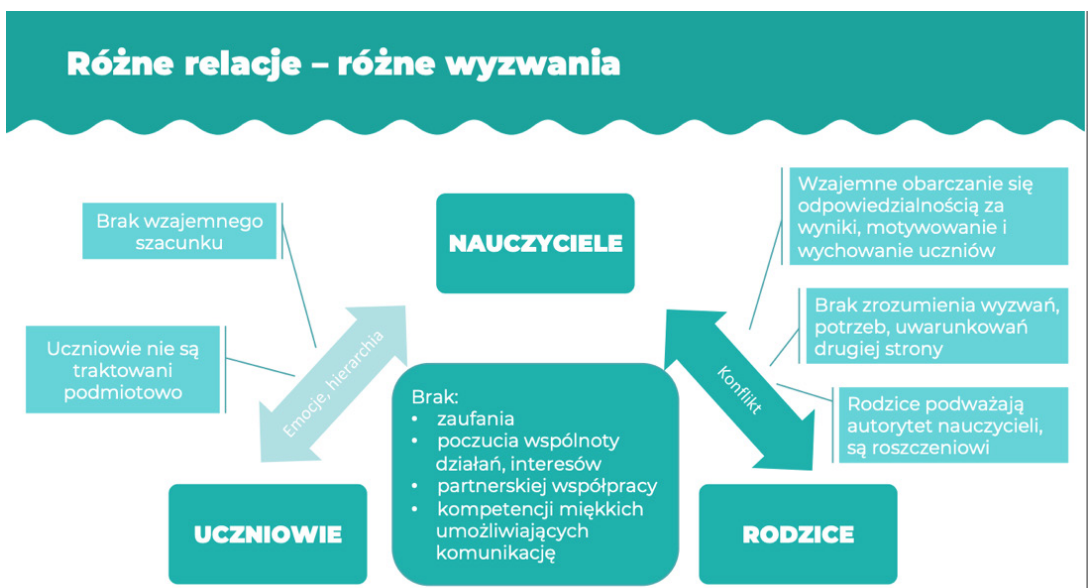

Ryc. 1. Relacje różne - różne wyzwania Źródło: „Narada obywatelska o edukacji, 2019: 18-28

Jest to dobra okazja na eksperymenty, zadania praktyczne, ćwiczenia zachowania się w czasie powodzi, trzęsienia ziemi, braku prądu, braku wody itp., a także wyjścia poza szkołę. Duże znaczenie ma środowisko szkolne - organizacja pracy, sposób podejmowania decyzji, wyposażenie.

Samorządy są organami prowadzącymi szkoły, ale ich wpływ na zarządzanie szkołami jest praktycznie bardzo ograniczony. Budżet oświatowy w istotnym stopniu zależy od wielkości subwencji oświatowej, którą samorządy otrzymują z budżetu państwa. Wszystkie kwestie merytoryczne, w tym przydział obowiązków nauczycieli, są kontrolowane przez kuratoria.

Wynagrodzenia nauczycieli i w dużym stopniu zakres obowiązków wynikają z Karty Nauczyciela. Z tego względu trudno jest prowadzić lokalną politykę oświatową. Niepodważalnie nauczyciele pomagają rozwijać pasje uczniów, aktywność obywatelską, współtworzą proces nauczania, za co należy się szacunek. Umiejętności i zachowanie nauczyciela kreuje autorytet nauczyciela wśród uczniów (ryc. 2).

Podstawa programowa (ryc. 3) jest powszechnie uważana za przeładowaną, niepozwalającą szkole przygotować uczniów do życia. Jest też zbyt sztywna i uniemożliwia autentyczną indywidualizację nauczania. Przeładowanie podstawy treściami, których nie da się zrealizować, sprawia, że nauczyciele nie nadążają z realizacją materiału, a uczniowie muszą nadrabiać zaległości w domu w formie prac domowych (Raport z narad obywatelskich, 2019: 33). 

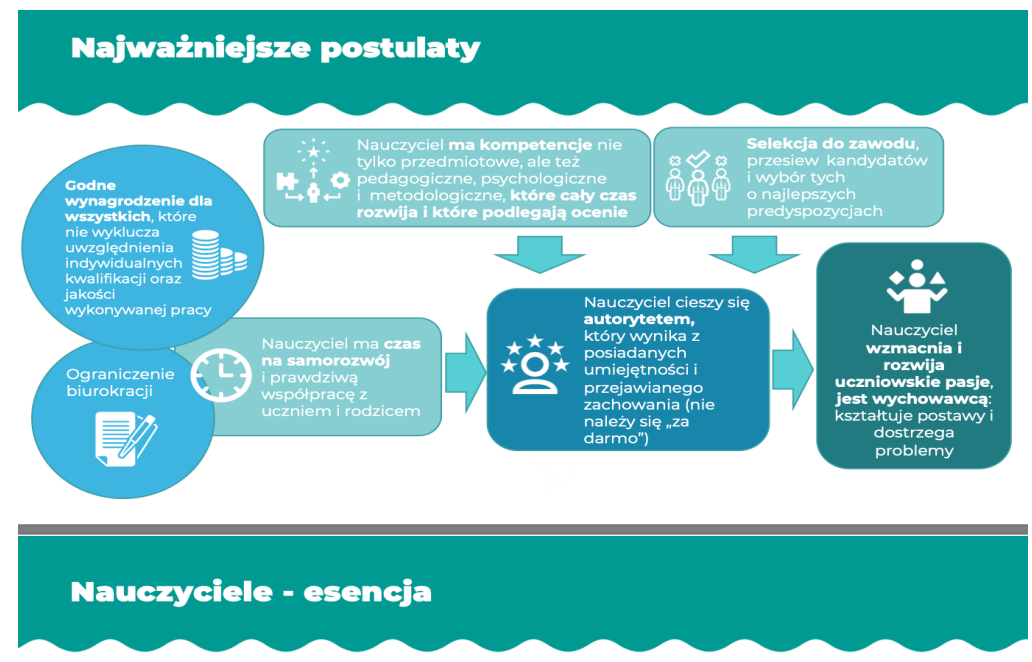

W sprawozdaniach z wielu narad pojawia się kwestia kompetencji nauczycieli. (...)Wyeliminowanie większości niedostatków wymaga rozwiq̨zań systemowych. Jednak na poziomie szkół można wprowadzać pewne rozwiązania w zakresie określania zadań nauczycieli (wykraczajace poza "pensum") oraz oceniania pracy zakresu zadań zodpowiednimi kompetencjami, bo brakuje narzędzi do mierzenia kompetencji nauczycielskich.

Dobrym rozwiqzaniem byłyby wzajemne, koleżeńskie oceny. To jednak wymaga zbudowania kultury wspótpracy i wzajemnego szacunku. W uzgadnianiu celów $i$ przydziale zadań powinni brać udziat rodzice.

Taki proces nie jest łatwy i pewnie, w wielu przypadkach wymagałby wsparcia ze strony fachowych mediatorów (co postulowano w czasie narad). Największa przeszkodq mogq być obawy samych nauczycieli wynikaja
samooceny i przekonania o niskim statusie społecznym.

Ryc. 2. Środowisko nauczyciela

Źródło: Narada obywatelska o edukacji..., 2019: 18-28

\section{Głóny hamulec edukacji}

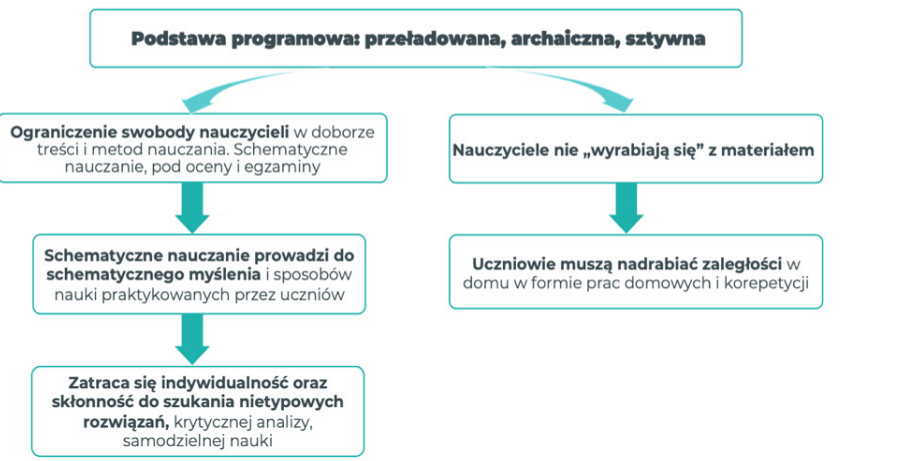

Ryc. 3. Wady podstawy programowej

Źródło: Narada obywatelska o edukacji..., 2019: 18-28 


\section{Reguły Jana Amosa Komensky'ego - wybrane zagadnienia}

Jan Amos Komensky proponuje uniwersalne rozwiązania. Celowe jest wskazanie zasad, które przedstawia na temat zmian w szkolnictwie. Temat jest aktualny, mimo iż dzieło powstało wieki temu. W oparciu o nie powstała propozycja kilku zmian metod nauczania edukacji dla bezpieczeństwa.

Filozof porównuje nauczyciela do lekarza zawsze przygotowanego do zajęć wraz z materiałami pomocniczymi, przyborami i książkami itp. (Komensky, 1633: 75). Zaznacza, iż teoria powinna wyprzedzać praktykę. Lekcje praktyczne przedmiotu edukacja dla bezpieczeństwa odbywają się rzadko. Głównie są to ćwiczenia z pierwszej pomocy. Dla poprawienia metody nauczania tego przedmiotu należy (Komensky, 1633:76):

- dostosować treści materiału do wieku ucznia, aby umożliwić zastosowanie zrozumiałej wiedzy w praktyce;

- pracować nad umiejętnością przedstawienia danej czynności w teorii, na przykład wykonanie ABC poszkodowanego;

- uwzględnić wielokrotne wykonanie danej czynności na etapie szkolenia, aby zachować pewność, że szkolony zastosuje ten sposób postępowania w życiu, na przykład kolejność wkładania odzieży ochronnej przeciw skażeniom;

- uczyć tematów, które mają zastosowanie w życiu, na przykład utrzymanie higieny osobistej;

- zwrócić uwagę na oczywistość ludzkich zachowań wynikających z natury człowieka, na przykład pragnienie życia, odkrycie niewypału.

\section{Wnioski}

Bezpieczeństwo kojarzy się i będzie się kojarzyć z istniejącym zagrożeniem. Wiele z tych zagrożeń wynika z działalności ludzkiej, z braku wiedzy i doświadczenia, nieudolności, niezaradności. Kształt edukacji jest formą umowy społecznej, która angażuje wiele instytucji oraz środowisk i powinna być wypracowywana razem.

Szkoła publiczna ma potencjał do integrowania społeczności lokalnej, ale także do jej informowania, edukowania i aktywizowania. Podkreślić należy, iż „każdy człowiek ma dość czasu, aby zdobyć tyle wiedzy, ile mu potrzeba i ile się od niego oczekuje; a ten, kto się nie stara o nią, gustuje widocznie w niewiedzy i jest za to odpowiedzialny" (Locke, 1955: 119-125). Zatem każdy jest w stanie osiągnąć pewien stopień rozwoju umysłowego. 
Zapał do nauki polega na woli, do której przymusić nie można. Mimo to ucznia należy wspierać. Najważniejszym elementem ideału człowieka, według Johna Locka, jest rozumność, umiejętność właściwego posługiwania się rozumem.

Być człowiekiem rozumnym to przede wszystkim panować nad sobą, być rozważnym, krytycznym, potrafić dokonać właściwej oceny sytuacji. Wymienione cechy są niezbędne do tego, aby móc korzystać z wolności, nie stanowiąc zagrożenia dla innych ludzi i porządku społecznego (Grabowska, 2011: 243). Taki cel powinien przyświecać szkołom oraz instytucjom, które pomagają w budowaniu wspólnego bezpieczeństwa.

Nauczyciel powinien mieć szansę decydowania o kierunku edukacji i wprowadzaniu własnych pomysłów w proces jej tworzenia.

Państwo może zmodyfikować strukturę podstawy programowej, wprowadzić zmiany w systemie kształcenia nauczycieli w ramach przygotowania praktycznego oraz szkoleń.

Rząd nie ma wyłączności na kreowanie systemu edukacji. Wiele pozytywnych zmian można wprowadzać lokalnie. Warto uczyć się od siebie nawzajem i wymieniać dobre praktyki horyzontalnie (pomiędzy samorządami, środowiskiem nauczycielskim, szkołami różnego typu). Stworzenie trwałego mechanizmu współpracy jest wyzwaniem dla instytucji oraz środowisk zaangażowanych w edukację XXI wieku.

Człowiek (uczeń) ufny $\mathrm{w}$ swoje siły, pewny swych umiejętności i zdolny do samokontroli nie ma powodu obawiać się wolności i godzić na przymus. $\mathrm{W}$ rozumności fakt ten należy brać pod uwagę projektując instytucje społeczne.

\section{Bibliografia}

Doroszewski W. (2009), Słownik języka polskiego, https://sjp.pwn.pl, dostęp: 7.04.2020.

Jakubczak R. (2006), Bezpieczeństwo narodowe Polski w XXI wieku. Wyzwania i strategie, Warszawa. Kant I. (2005), Rozprawy z filozofii historii, http://www.bibliotekacyfrowa.pl/Content/32192/0003. pdf, dostęp: 7.04.2020.

Kmita A. (1991), Lęk w szkole, Życie Szkoły, 5 (91).

Knopka J. (2009), Integracja europejska a lokalność, Acta Pomerania, 2, http://www.pomeraniachojnice.edu.pl/wp-content/uploads/rozne/Acta_nr2-tekst.pdf, dostęp: 7.04.2020.

Komensky J.A. (1633), Wielka dydaktyka, http://www.literatura.hg.pl/komenski.htm, dostęp: 7.04.2020.

Kupś T. (2005), Idem. Rozprawy z filozofii historii, Kęty.

Locke J. (1955), Rozważania dotyczace rozumu ludzkiego, O ideałach w ogólności i ich pochodzeniu, II, s. 119-125, http://hamlet.edu.pl/locke-epistemologia, dostęp: 7.04.2020.

Locke J. (1959), Myśli o wychowaniu, Wrocław-Kraków. 
Narada obywatelska o edukacji (2019), Raport z Narad Obywatelskich o Edukacji, https://www.naradaobywatelska.pl, dostęp: 7.04.2020.

Biuro Bezpieczeństwa Narodowego (2014), Strategia Bezpieczeństwa Narodowego, https://www.bbn. gov.pl/ftp/SBN\%20RP.pdf, dostęp: 7.04.2020.

Pieczywok A. (2011), Wybrane problemy z zakresu edukacji dla bezpieczeństwa. Konteksty zagrożenia - wyzwania, Warszawa.

Szubrycht T. (2016), Współczesne aspekty bezpieczeństwa państwa, Zeszyty Naukowe Akademii Marynarki Wojennej, vol. 47, nr 4 (167).

Szymaniec P. (2009), Państwo i prawo w filozofii dziejów Immanuela Kanta, Wrocław

Żelazna J. (2011), Filozofia XVII w. Twórcy problemy, kontynuacje, Toruń. 